\title{
Extended Spectrum Beta Lactamases and Class-I Integrons Producing Escherichia coli in Pigs of North Eastern States of India
}

\author{
Rajkumari Mandakini ${ }^{1}$, T. K. Dutta ${ }^{2}$, Hosterson Kylla ${ }^{2}$, \\ Parimal Roychoudhury ${ }^{2}$ and P. K. Subudhi ${ }^{2}$ \\ ${ }^{1}$ Department of Veterinary Microbiology, College of Veterinary Sciences \& Animal \\ Husbandry, CAU (Imphal), Jalukie, Peren, Nagaland \\ ${ }^{2}$ Department of Veterinary Microbiology, College of Veterinary Sciences \& Animal \\ Husbandry, CAU (Imphal), Selesih, Aizawl-796014, Mizoram \\ *Corresponding author
}

\section{A B S T R A C T}

\begin{tabular}{|l|}
\hline Ke y w or d s \\
$\begin{array}{l}\text { E. coli, ESBLs, } \\
\text { Integrons, Pigs, } \\
\text { India }\end{array}$ \\
\hline Article Info \\
\hline $\begin{array}{l}\text { Accepted: } \\
\text { 04 December } 2020 \\
\text { Available Online: } \\
\text { 10 January } 2021\end{array}$ \\
\hline
\end{tabular}

The aim of this study was to determine the prevalence of extended spectrum beta lactamases (ESBLs) associated genes and integron elements in Escherichia coli from faeces of pigs in North eastern (NE) states of India. A total of 790 faecal samples were collected from pigs maintained under organized as well as individual house hold irrespective of age, sex and with or without history of diarrhea from all the eight states of NE region. A total of $2291 \mathrm{E}$. coli were isolated and identified. All the isolates were subjected to antimicrobial susceptibility test against 18 antimicrobial agents by disk diffusion method. The selected ESBLs genes $\left(\right.$ bla $_{S H V}, b l a_{T E M}, b l a_{C M Y}$ and $\left.b l a_{C T X-M}\right)$ and integron (IntII and IntI2) genes were detected by specific PCR assay. A total of 366 $(15.98 \%)$ and $80(3.49 \%)$ isolates were positive for IntII and ESBLs, respectively. Twenty four $(1.05 \%)$ isolates positive for IntII were carrying multiple ESBLs genes, and individually $0.17 \%, 1.92 \%, 0.17 \%$ and $0.17 \%$ isolates were positive for bla $a_{S H V}$, bla $_{T E M}$, $b l a_{C M Y}$ and $b l a_{C T X-M}$ genes, respectively. Class 2 integrons (IntI2) were not detected in any of the E. coli isolates under the study. It may be concluded that E. coli isolates with multiple ESBL genotypes have a greater opportunity to carry Class 1 integron and can be a potential to exhibit stronger multi-drug resistance activity.

\section{Introduction}

Antimicrobial resistance (AMR) is a potential threat to human and animal health. Antimicrobial agents are extensively used in livestock due to increasing demand for animal protein. Inappropriate use of antibiotics appears to be the major cause of increase in AMR bacteria. In Enterobacteriaceae family,
Escherichia coli are the most common commensal bacteria in the gastrointestinal tract of humans and animals (Chen et al., 2019). E. coli have a considerable potential of accepting and transferring plasmids, which under stress readily transfers it to other species. Therefore, it is considered an important reservoir of transferable antibiotic resistance (Chamosa et al., 2017; 
Leungtongkam et al., 2018). The distribution of broad-spectrum beta-lactams resistant enterobacterial strains along with coresistance to other antibiotic families are emerging as a potential threat to animal and public health (EFSA, 2013). These resistance genes are greatly enhanced, when they are trapped in a mobile gene cassette, the so called integron (White et al., 2001). Integrons are conserved DNA sequences that provide an efficient means for capturing and spreading of antimicrobial resistance genes (Peymani et al., 2012).

The component of an integron includes integrase gene (IntI), attachment site (AttI), and promoter (Pant) region, which promotes the expression of any suitably integrated gene(s). Integrase is a member of the tyrosine site specific recombinase family that catalyzes the excision and integration of DNA units by performing two consecutive strand breakages and rejoining steps (Ahangarzadeh et al., 2011).

Four classes of integrons so far identified are distinguished by their respective integrase (Int) genes. Most of the resistance integrons found in clinical isolates of Enterobacteriaceae are class 1 integrons, which are highly associated with widespread incidence and spread of antibiotic resistance to antimicrobial agents (Ghaly, et al., 2017). Integrons are of clinical importance, because the use of only one antibiotic may activate the expression of a whole gene cassette. There is paucity of information so far on detection of integrons in multi drug resistant (MDR) isolates of E. coli from pigs, particularly in India. Therefore, the present study was aimed to determine the prevalence of $E S B L$ genes and the frequency of class 1 and 2 integrons in $E$. coli isolated from pigs in the NE states and also to investigate the association between $E S B L$ genes and existence of integrons.

\section{Materials and Methods}

\section{Isolation and Identification of $E$. coli}

A total of 790 fresh faecal samples were collected randomly from pigs of all the eight NE states maintained under organized as well as individual house hold. Samples were collected irrespective of age, sex and history of diarrhea of the animals. All the samples were collected using sterilized absorbent cotton swab under aseptic conditions. However, for collection of samples from distant locations, a sterilized swab dipped in brain heart infusion broth (HiMedia, Mumbai) was used as transport medium and transported to the laboratory under cold chain for further processing. The organisms were isolated and identified as per standard bacteriological techniques including cultural characteristics and biochemical tests (Quinn et al., 2004).

\section{Antimicrobial susceptibility assay}

All the isolates were subjected to antimicrobial susceptibility assay by disc diffusion method on Mueller-Hinton agar (HiMedia, Mumbai) plate as per the recommendation of Clinical Laboratory Standard Institute (CLSI, 2018) against 18 commercially available antibiotic discs: amoxicillin (AMX, $30 \mathrm{mcg}$ ), ampicillin (AMP, $10 \mathrm{mcg}$ ), aztreonam (Az, $30 \mathrm{mcg}$ ), cefalexin $(\mathrm{CN}, 30 \mathrm{mcg})$, cefexime (CFM, 30 $\mathrm{mcg}$ ), cefotaxime (CTX, $30 \mathrm{mcg}$ ), ceftazidime (CAZ, $30 \mathrm{mcg}$ ), ceftriaxone (CTR, $30 \mathrm{mcg}$ ), ciprofloxacin (CIP, $5 \mathrm{mcg}$ ), co-trimoxazole (COT, 1.25/23.75 mcg), gentamicin (GEN, 10 $\mathrm{mcg}$ ), imipenem (IPM, $10 \mathrm{mcg}$ ), nalidixic acid (NA, $30 \mathrm{mcg}$ ), piperacillin (PI, $100 \mathrm{mcg}$ ), streptomycin $(\mathrm{S}, 10 \mathrm{mcg})$, sulphafurazole/ sulfisoxazole (SF, $300 \mathrm{mcg}$ ), tetracycline (TE, $30 \mathrm{mcg}$ ) and trimethoprim (TR, $30 \mathrm{mcg}$ ). Further, the isolates exhibiting resistance to the extended-spectrum cephalosporin group of antibiotics were screened for ESBL 
production using a double disk synergy test (DDST) for cefotaxime (30 mcg), amoxicillin (30 $\mathrm{mcg})$ and ceftazidime $(30 \mathrm{mcg})$ alone as well as cefotaxime/clavulanate $(30 / 10 \mathrm{mcg})$, amoxicillin/clavulanate $\quad(30 / 10 \quad \mathrm{mcg})$ andceftazidime/clavulanate $\quad(30 / 10 \quad \mathrm{mcg})$ combination as per the recommendation of CLSI (2018). Difference in zone diameters with and without clavulanic acid was measured. E. coli ATCC 25922 was used as control organisms. An increase of $\geq 5 \mathrm{~mm}$ in inhibition zone diameter around antimicrobial agent tested in combination with clavulanic acid versus its inhibition diameter zone tested alone was confirmed as potent ESBLs producing isolates.

\section{Detection of ESBL genes by PCR}

Presence of selected ESBLs (bla $a_{S H V}, b l a_{T E M}$, bla $_{C M Y}$ and bla $\left._{C T X-M}\right)$ genes were detected by PCR assay using specific primers (Table-1). Bacterial DNA was prepared from all the isolates, which were positive for ESBLs production phenotypically as described earlier (Dutta et al., 2013). PCR was carried out in a thermal cycler (Eppendorf, Germany) and visualized under UV transilluminator followed by documentation using Gel documentation system (Alpha Imager, USA) as described elsewhere (Dutta et al., 2013). All the PCR products were purified and subsequently sequenced by Sanger's method at University of Delhi, South Campus, Department of Biochemistry, Benito Juarez Road, New Delhi-110021. The DNA sequences were analysed for genetic relatedness with published sequences and submitted to Genbank, NCBI.

\section{Detection of class 1and 2 integrons by PCR}

All the isolates positive for $E S B L$ genes were further screened for the presence of class 1 (IntI1) and 2 (IntI2) integrons as well as its gene cassettes $5 \mathrm{CS} / 3 \mathrm{CS}$ and TiB/TiF by PCR assay using specific primers (Table-1). Further, the amplification of variable region of class 1 and class 2 integrons were performed using the primers 5'-CS/3'-CS and Ti-F/Ti-B, as per the procedures described previously (Zhang et al., 2004).

\section{Results and Discussion}

Multi Drug Resistant (MDR) bacteria, particularly the enteric bacteria including $E$. coli are becoming a great threat globally. In India, although sporadic reports of MDR bacteria in animals are available but there is very little information available on association of class I integrons and ESBLs genes in E. coli of animal origin. The present study was focused to investigate the prevalence of Class I integrons and ESBLs producing $E$. coli isolates from pigs of $\mathrm{NE}$ states of India with the broad objective to improve the practice of antimicrobials use in clinical practice, farm biosecurity, epidemiological studies and also safeguarding against the zoonotic outbreaks by MDR bacteria in human and animal population. A total of 2291 bacterial isolates recovered from 790 faecal samples were identified as E. coli on the basis of standard cultural characteristics and biochemical tests. All the isolates exhibited small, bright pink colonies on MacConkey's (MLA) agar and a characteristic metallic sheen on eosin methylene blue (EMB) agar medium. Biochemically, all isolates were positive for indole and methyl red tests and negative for oxidase, Voges-Proskauer and citrate utilization tests. Also, all the isolates fermented glucose, sucrose and lactose with production of gas. The antimicrobial resistance pattern of $E$. coli isolated is depicted in Table-2. All the isolates showed resistance to at least 3 antimicrobial agents with highest resistance to amoxycillin (84.81\%) and lowest resistance to imipenem $(0.22 \%)$. Further, on screening by DDST 
method, a total of 654 (28.55\%) isolates were suspected for ESBL producers of which 136 $(5.94 \%), 65(2.84 \%), 49(2.14 \%)$ and 23 $(1.00 \%)$ were found to be positive for bla ${ }_{T E M}$, bla $_{C T X-M}$, bla $_{C M Y}$ and $b l a_{S H V}$ gene respectively in specific PCR assay. With the present data it may not be possible to conclude with a statement on the prevalence of ESBL genes in the $E$. coli isolates from pigs in this region. Based on the published evidences, we have targeted only 4 major ESBL genes out of estimated genes of more than 500 for detection, which are associated with resistance against beta lactam antibiotics applied for treatment in men and animals. Previously, several workers from India and abroad have also reported the prevalence of ESBLs producers varying from $6.6 \%$ to $91 \%$ from time to time (Jain et al., 2003; Wattal et al., 2005; Bhattacharjee et al., 2008; Basavaraj et al., 2011). In India, Basavaraj et al., (2011) reported 27.9\% Enterobacteriaceae organism as ESBLs producer by DDST, in which $E$. coli and $K$. pneumoniae were the major ESBLs producers. Interestingly, in the present study imipenem underperformed against $E$. coli isolates. Earlier, Patrícia et al., (2010) and Aly et al., (2012) reported no resistance against imipenem.

The class 1 and 2 integrons gene in ESBLproducing $E$. coli isolates from NE states of India was screened by PCR assay. We found, a total of $366(15.98 \%)$ E. coli isolates were positive for Class1 integrons. However, Class 2 integrons (IntI2) were not detected in any of the isolates. Prevalence of class 1 integron gene in ESBL-producing $E$. coli isolated from NE states of India is depicted in Table 3. Altogether 80 (3.49\%) of E. coli isolates were positive for both ESBLs genes and class 1 integrons. Previously, it was reported that class 1 integrons are the most common antibiotic resistant genes found in the clinical isolates of Gram-negative bacteria (Betteridge et al., 2011; Ribeiro et al., 2011).

Table.1 Details of the oligonucleotide Primers used in the present study

\begin{tabular}{|c|c|c|c|c|}
\hline $\begin{array}{l}\text { Primer } \\
\text { name }\end{array}$ & Sequence $\left(5^{\prime} \rightarrow 3^{\prime}\right)$ & $\begin{array}{l}\text { Expected } \\
\text { amplicon } \\
\text { size (bp) }\end{array}$ & $\begin{array}{c}\text { Annealing } \\
\text { temperature } \\
\left({ }^{\circ} \mathrm{C}\right)\end{array}$ & Reference \\
\hline bla $_{T E M}$ & $\begin{array}{l}\text { ATAAAATTCTTGAAGACGAAA } \\
\text { GACAGTTACCAATGCTTAATC }\end{array}$ & 1080 & 53 & $\begin{array}{l}\text { Weill Francois- } \\
\text { Xavier et al., (2004) }\end{array}$ \\
\hline bla $_{S H V}$ & $\begin{array}{l}\text { CTTTCCCATGATGAGCACCT } \\
\text { CGCTGTTATCGCTCATGGTA }\end{array}$ & 206 & 60 & This study \\
\hline $\begin{array}{l}\text { bla }_{C T X-} \\
\text { M }\end{array}$ & $\begin{array}{l}\text { CAATGTGCAGCACCAGTAA } \\
\text { CGCGATATCGTTGGTGGTG }\end{array}$ & 540 & 58 & $\begin{array}{l}\text { Perez and } \\
\text { Hanson,2002 }\end{array}$ \\
\hline bla $_{C M Y}$ & $\begin{array}{l}\text { TGGCCAGAACTGACAGGCAAA } \\
\text { TTTCTCCTGAACGTGGCTGGC }\end{array}$ & 462 & 60 & $\begin{array}{l}\text { Perez and } \\
\text { Hanson,2002 }\end{array}$ \\
\hline IntI1 & $\begin{array}{l}\text { GGGTCAAGGATCTGGATTTCG } \\
\text { ACATGGGTGTAAATCATCGTC }\end{array}$ & 483 & 60 & Mazel et al., (2000) \\
\hline IntI2 & $\begin{array}{l}\text { CACGGATATGCGACAAAAAGGT } \\
\text { GTAGCAAACGAGTGACGAAATG }\end{array}$ & 788 & 60 & Mazel et al., (2000) \\
\hline $\begin{array}{l}5^{\prime}-\mathrm{CS} \\
3^{\prime}-\mathrm{CS}\end{array}$ & $\begin{array}{l}\text { GGCATACAAGCAGCAAGC } \\
\text { AAGCAGACTTGACCTGAT }\end{array}$ & variable & 52 & Zhang et al., (2004) \\
\hline $\begin{array}{l}\text { Ti-F } \\
\text { Ti-B }\end{array}$ & $\begin{array}{l}\text { ACCTTTTTGTCGCATATCCGTG } \\
\text { CTAACGCTTGAGTTAAGCC }\end{array}$ & variable & 55 & Su et al., (2006) \\
\hline
\end{tabular}


Table.2 Antimicrobial resistance pattern of $E$. coli isolated from faecal samples of pig of NE states of India

\begin{tabular}{|l|c|c|c|c|}
\hline \multirow{2}{*}{ Antimicrobial agents } & \multicolumn{4}{|c|}{ No. of isolates } \\
\cline { 2 - 5 } & S & \% & R & \% \\
\hline Amoxicillin (AMX) & 348 & 15.19 & 1943 & 84.81 \\
\hline Ampicillin (AMP) & 1686 & 73.91 & 595 & 26.09 \\
\hline Aztreonam (AT) & 1862 & 81.63 & 419 & 18.37 \\
\hline Cefalexin(CN) & 523 & 22.83 & 1768 & 77.17 \\
\hline Cefexime (CFM) & 1474 & 64.34 & 817 & 35.66 \\
\hline Cefotaxime (CTX) & 2102 & 91.75 & 189 & 8.25 \\
\hline Ceftazidime (CAZ) & 1767 & 77.13 & 524 & 22.87 \\
\hline Ceftriaxone(CTR) & 2119 & 92.49 & 172 & 7.51 \\
\hline Ciprofloxacin (CIP) & 2151 & 93.89 & 140 & 6.11 \\
\hline Co-Trimoxazole(COT) & 1651 & 72.06 & 640 & 27.94 \\
\hline Gentamicin (GEN) & 1940 & 83.73 & 377 & 16.27 \\
\hline Imipenem (IPM) & 2286 & 99.78 & 5 & 0.22 \\
\hline Nalidixic acid (NA) & 1791 & 78.18 & 500 & 21.82 \\
\hline Piperacillin (PI) & 1228 & 53.60 & 1063 & 46.40 \\
\hline Streptomycin (S) & 2082 & 90.88 & 209 & 9.12 \\
\hline Sulphafurazole & 990 & 43.21 & 1301 & 56.79 \\
\hline (sulfisoxazole)(SF) & & & & \\
\hline Tetracycline (TE) & 1415 & 61.71 & 878 & 38.29 \\
\hline Trimethoprim(TR) & 1688 & 73.68 & 603 & 26.32 \\
\hline
\end{tabular}

*S- sensitive, R-resistant

Table.3 Prevalence of class 1 integron gene in ESBL-producing E. coli isolated from NE states of India

\begin{tabular}{|r|l|c|}
\hline Sl. No. & ESBL gene(s) & $\begin{array}{c}\text { No. of class1 integron positive } \\
\text { strains }\end{array}$ \\
\hline 1. & bla $_{T E M}$ & $44(1.92 \%)$ \\
\hline 2. & bla $_{S H V}$ & $4(0.17 \%)$ \\
\hline 3. & bla $_{C T X-M}$ & $4(0.17 \%)$ \\
\hline 4. & bla $_{C M Y}$ & $4(0.17 \%)$ \\
\hline 5. & bla $_{T E M}+$ bla $_{C M Y}$ & $7(0.30 \%)$ \\
\hline 6. & bla $_{T E M}+$ bla $_{C T X-M}$ & $12(0.52 \%)$ \\
\hline 7. & bla $_{T E M}+$ bla $_{C T X-M}+$ bla $_{C M Y}$ & $3(0.13 \%)$ \\
\hline 8. & bla $_{T E M}+$ bla $_{C M Y}+$ bla $_{S H V}$ & $1(0.04 \%)$ \\
\hline 9. & bla $_{T E M}+$ bla $_{C T X-M}+$ bla $_{S H V}$ & $1(0.04 \%)$ \\
\hline Total numbers of E. coli isolates $=\mathbf{2 2 9 1}$ & $80(3.49 \%)$ \\
\hline
\end{tabular}

The class 1 integron was observed in $43 \%$ of the strains isolated from animals and humans, while the class 2 integrons was observed in only $1 \%$ (van Essen-Zandbergen et al., 2007). 
In another study conducted by Zeeshan Khan et al., (2018), 79\% of MDR E. coli isolates was recorded with class 1 integrons. Integrons have been identified as a primary source of resistance genes and are claimed to be reservoirs of antimicrobial resistance genes within microbial populations (Nijssen et al., 2005).As far as pig is concerned, Gebreyes and Thakur (2005) reported that of the 28 isolates, 21 were multidrug resistant and all of them harboured the class 1 integron. However, Martin et al., (2008) could detect both class 1 and class 2 integrons in nearly similar proportions in Salmonella spp. isolated from healthy swine from 126 different farms of Chile. Integron gene sequences contribute to the spread of antimicrobial resistance alleles by lateral gene transfer of gene cassettes in a variety of enteric bacteria including Campylobacter spp., Escherichia coli and Salmonella enterica subsp. enterica serotype Typhimurium (Roe et al., 2003). As indicated above, in the present study, class 1 integron was detected in $15.98 \%$ of $E$. coli isolates of swine, which was comparatively lower than the reports by other workers (Phongpaichit et al., 2011; Pongpech et al., 2008). This may be an indication that there is comparatively less selection pressure on integron-positive $E$. coli isolates in NE states of India. Various workers in different countries also mentioned that the accumulation of resistance genes by integrons is an important factor in the development of multi-drug-resistant $E$. coli strains. Phongpaichit et al., (2011) reported that $74.7 \%$ of ESBL-producing $E$. coli was integron-positive isolates. Similarly, Chen et al., (2013) also found that 69\% of clinical ESBL-producing isolates were carrying class 1 integron.

Analysis on correlation between integrons and ESBL genes (Table 3) indicated that 24 $\left[b l a_{T E M+C M Y}(12), b l a_{T E M}+b l a_{C T X-M}+b l_{C M Y}\right.$ (3), bla $a_{T E M}+b l a_{C M Y}+b l a_{S H V}(1), b_{a_{T E M+}} b a_{C T X}-$ $\left.{ }_{M+} \operatorname{bla}_{S H V}(1)\right]$ isolates were positive for multiple ESBL genes and class 1 integron. At the same time, individually, $1.92 \%, 0.17 \%$, $0.17 \%$ and $0.17 \%$ of the isolates positive for class 1 integrons were also positive for bla $_{T E M}, b a_{C T X-\mathrm{M}}, b l a_{C M Y}$ and bla $a_{S H V}$ genes, respectively. Our result indicated that class 1 integron were more commonly associated with the $b l a_{T E M}$ gene than with the other three genes, suggesting that in ESBL-producing isolates, bla $a_{T E M}$ carriers were more closely related to class 1 integron, which may be due to genetic linkage between them. Chen et al., (2013) also reported that class 1 integron was more commonly associated with the bla $a_{T E M}$ gene than bla $_{C T X-\mathrm{M}}$, bla $_{C M Y}$ or bla $a_{S H V}$ genes. Association between antibiotic resistance integrons and $b l a_{S H V-5}$ as well as co-location of bla $a_{S H V-12}$ and a class 1 integron on the same plasmid have been reported by Jones et al., (2005) and Gruteke et al., (2003). However, other investigators reported a low rate of association between integrons and ESBL genes with the exception of bla $a_{C T X-M-9}$ (Machado et al., 2007). In this study, the rates of combination of at least two different ESBL genotypes along with class 1 integron were variable, in which the combination of bla $_{T E M}+$ bla $_{\text {CTX-M }}(0.79 \%)$ was highest.

The present study demonstrated the E. coli isolates from pigs of $\mathrm{NE}$ states are a major carrier of class I integrons and ESBL genes. In addition, multiple ESBL genotypes have a greater opportunity to carry class 1 integron. Therefore, bacteria carrying both integrons and ESBL genes have stronger MDR potential.

\section{References}

Ahangarzadeh Rezaee M, Sheikhalizadeh V, Hasani A. Detection of integrons among multi-drug resistant (MDR) (2011). Escherichia coli strains isolated from clinical specimens in 
northern west of Iran. Braz $J$ Microbiol. 42:1308-1313.

Aly MEA, Essam TM, Amin MA (2012). Antibiotic resistance profile of $E$. coli strains isolated from clinical specimens and food samples in Egypt. Intl Microbiol Res 3 (3): 176-182.

Basavaraj MC, Jyothi P, Basavaraj VP (2011). The prevalence of ESBL among Enterobacteriaceae in a Tertiary Care Hospital of North Karnataka, India. J Clin Diag Res 5(3): 470-475.

Belanger L, Garenaux A, Harel J, Boulianne M, Nadeau E, Dozois CM (2011). Escherichia coli from animal reservoirs as a potential source of human extraintestinal pathogenic E. coli. FEMS Immunol Med Microbiol 62:110.

Betteridge T, Partridge SR, Iredell JR, Stokes HW (2011). Genetic context and structural diversity of class 1 integrons from human commensal bacteria in a hospital intensive care unit. Antimicrob Agents Chemother 55: 3939-3943.

Bhattacharjee A, Sen MR, Prakash P, Gaur A, Anupurba S (2008). Increased prevalence of extended-spectrum $\beta$ lactamase producers in neonatal septicaemic cases at a tertiary referral hospital. Indian Med Microbiol 26(4): 356-360.

Chamosa LS, Álvarez VE, Nardelli M, Quiroga MP, Cassini MH, Centrón D. Lateral Antimicrobial (2017). Resistance Genetic Transfer is active in the open environment. Sci Rep 7:513.

Chen M, Wu Y, Yu S, Liu S, Wang Y, Huang D, Xu X, Lin F (2019). Drug resistance and integron genes in Escherichia coli isolated from urinary tract infection. $J$ Nanosci Nanotechnol 19: 5989-5993.

Chen T, Feng Y, Yuan JL, Qi Y, Cao YX, Wu $Y$ (2013). Class 1 integrons contributes to antibiotic resistance among clinical isolates of Escherichia coli producing extended-spectrum betalactamases. Indian J Med Microbiol 31(4): 385389.

CSLI (2008). Performance standard for antimicrobial susceptibility testing. 18th Informational Supplement. CLSI Document M100-S18 Wayne, PA.

EFSA Panel (EFSA Panel on Food Additives and Nutrient Sources added to Food) (2013). Scientific opinion on the reevaluation of aspartame (E 951) as a food additive. EFSA Journal 11: 3496.

Gebreyes WA, Thakur S (2005). Multidrugresistant Salmonella enterica Serovar Muenchen from pigs and humans and potential interserovar transfer of antimicrobial resistance. Antimicrob Agents Chemother 49(2): 503-511.

Ghaly TM, Chow L, Asher AJ, Waldron LS, Gillings MR (2017). Evolution of class 1 integrons: mobilization and dispersal via food-borne bacteria PLoS One 12:e0179169.

Gruteke P, Goessens W, Van Gils J, Peerbooms P, Lemmens-Den Toom N, Van Santen-Verheuvel

Jones LA, McIver CJ, Kim MJ, Rawlinson WD, White PA (2005). The aadB gene cassette is associated with blaSHV genes in Klebsiella species producing extended-spectrum betalactamases. Antimicrob Agents Chemother 49(2): 794-797.

Labbate M, Case RJ, Stokes HW (2009). The integron/gene cassette system: An active player in bacterial adaptation. Methods Mol Biol 532: 103-125.

Leungtongkam U, Thummeepak R, Tasanapak K, Sitthisak S (2018). Acquisition and transfer of antibiotic resistance genes in association with conjugative plasmid or class 1 integrons of Acinetobacter baumannii PLoS One 13:e0208468.

Machado E, Ferreira J, Novais A, Peixe L, 
Canton R, Baquero F, et al., (2007) Preservation of integron types among Enterobacteriaceae producing extended-spectrum beta-lactamases in a Spanish hospital over a 15-year period (1988 to 2003). Antimicrob Agents Chemother 51(6): 2201-2204.

Martin BS, Lapierre L, Cornejo J, Bucarey S (2008) Characterization of antibiotic resistance genes linked to class 1 and class 2 integrons in strains of Salmonella spp. isolated from swine. Canadian J Microbiol 54: 1-8.

Mazel D, Dychinco B, Webb VA, Davies J. (2000) Antibiotic resistance in the ECOR collection:integrons and identification of a novel aad gene. Antimicrob Agents Chemother 44:1568-1574.

Nijssen S, Florijin J, Willems R, Fluit A, Bonten M (2005) Unnoticed spread of integron-carrying Enterobacteriaceae in intensive care unit. Clin Infect Dis 41: 1-9.

Ochman H, Lawrence JG, Groisman EA (2000) Lateral gene transfer and the nature of bacterial innovation. Nature 405: 299-304.

Patrícia G, Garcia L, Silva V, Diniz CG (2010) Occurrence and antimicrobial drug susceptibility patterns of commensal and diarrheagenic Escherichia coli in fecal microbiota from children with and without acute diarrhea. J Microbiol 49(1): 46-52.

Perez FJ, Hanson ND (2002) Detection of Plasmid-Mediated AmpC $\beta$-Lactamase Genes in Clinical Isolates by Using Multiplex PCR. J Clin Microbiol 40 (6) 2153-2162.

Peymani A, Farajnia S, Nahaei MR, Sohrabi $\mathrm{N}$, Abbasi L, Ansarin $\mathrm{KH}$, et al., (2012) Prevalence of class 1 integron among multidrug-resistant Acinetobacter baumannii in Tabriz, northwest of Iran. Pol J Microbiol
61:57-60.

Phongpaichit S, Tunyapanit W, Pruekprasert P (2011) Antimicrobial resistance, class 1 integrons and extendedspectrum beta-lactamases in Escherichia coli clinical isolates from patients in South Thailand. J Hlth Sci 57: 281-288.

Pongpech P, Naenna P, Taipobsakul Y, Tribuddharat C, Srifuengfung S (2008) Prevalence of extended-spectrum betalactamase and class 1 integron integrase gene intIl in Escherichia coli from Thai patients and healthy adults. Southeast Asian J Trop Med Pub Hlth 39: 425-433.

Quinn PJ, Carter ME, Markey B, Carter GR (2004) Clinical Veterinary Microbiology. London, UK: Mosby International 209-236.

Rao AN, Barlow M, Clark LA, Boring JR, Tenover FC, McGowan JE Jr. Class 1 Integrons in resistant Escherichia coli and Klebsiella spp. (2006) US Hospitals. Emerg Infect Dis 12:10111014.

Ribeiro VB, Lincopan N, Landgraf M, Franco BD, Destro MT (2011) Characterization of class 1 integrons and antibiotic resistance genes in multidrug-resistant Salmonella enteric isolates from foodstuff and related sources. Braz J Microbiol 42: 685-692.

Roe MT, Vega E, Pillai SD (2003) Antimicrobial resistance markers of class 1 and class 2 integron bearing Escherichia coli from irrigation water and sediments. Emerg Infect Dis 9: 822-826.

Su J, Shi L, Yang L, Xiao Z, Li X, Yamasaki $S$ (2006) Analysis of integrons in clinical isolates of Escherichia coli in China during the last six years. FEMS Microbiol Lett 254: 75-80.

Van Essen- Zandbergen A, Smith H, Veldman K, Mevius D (2007) 
Occurrence and characteristics of class 1, 2 and 3 integrons in Escherichia coli, Salmonella and Campylobacter spp. In the Netherlands. J Antimicrob Chemother 59: 746-750.

Weill FX, Demartin M, Tande D, Espie E, Rakotoarivony I, Grimont PAD (2004) SHV-12-Like Extended-SpectrumLactamase-Producing Strains of Salmonella enterica Serotypes Babelsberg and Enteritidis Isolated in France among Infants Adopted from Mali. J Clin Microbiol 42(6): 2432 2437.
White PA, Christopher JM, William DR (2001) Integrons and gene cassettes in the Enterobacteriaceae. Antimicrob Agents Chemother 45:2658-2661.

Zhang HM, Shi L, Li L, Guo SY, Zhang XM, Yamasaki S, Miyoshi S, Shinoda S (2004) Identification and characterization of class 1 integron resistance gene cassettes among Salmonella strains isolated from healthy humans in China. Microbiol Immunol 48: 639-645.

\section{How to cite this article:}

Rajkumari Mandakini, T. K. Dutta, Hosterson Kylla, Parimal Roychoudhury and Subudhi, P. K. 2021. Extended Spectrum Beta Lactamases and Class-I Integrons Producing Escherichia coli in Pigs of North Eastern States of India. Int.J.Curr.Microbiol.App.Sci. 10(01): 207-215. doi: https://doi.org/10.20546/ijcmas.2021.1001.025 